\title{
TARI BALANSE MADAM : MEDIA SOSIALISASI ETNIK NIAS
}

\author{
oleh Indra Yuda \\ FBS Universitas Negeri Padang
}

\begin{abstract}
Balanse Madam dance is a cultural and inherrited dance on the Nias ethnic of Padang, West Sumatera. As a traditional dance, Balanse dance is arranged in accordance with the cultural values of the Nias ethnic who live in Padang. One of the rugaltions is that is only performed for wedding ceremonies. When it is used for wedding ceremonies, the balanse dance functions as a social gathering media among the Nias ethnic of Padang.
\end{abstract}

Key words : Tari Balanse Madam, Etnik Nias dan Sosialisasi

\section{A. Pendahuluan}

Kesenian dimiliki secara komunal oleh masyarakat, sehingga melekat erat dengan nilai dan norma yang berlaku di tengah-tengah masyarakat pendukungnya. Seni komunal adalah bagian dari kehidupan masyarakat yang tidak dapat begitu saja ditarik dari masyarakatnya. Kesenian seperti itu disebut kesenian tradisional. Setiap kesenian tradisional mencerminkan dan mengungkapkan berbagai makna kultural yang ada dalam kehidupan sosial masyarakat yang memiliki kesenian itu (Mustika, 1990: 8).

Kesenian juga merupakan bahasa, tanda, atau simbol dari suatu etnik tertentu. Dengan menciptakan suatu bentuk kesenian dan pada gilirannya mempertunjukkan kepada orang lain, secara tidak langsung masyarakat yang memiliki kesenian tersebut berusaha untuk berkomunikasi atas kehidupannya dengan dunia di luar etniknya. Jalinan komunikasi tersebut dibangun lewat media karya seni. Karya seni berfungsi sebagai jembatan komunikasi yang berupa sumbersumber informasi. Karena itu, kesenian, seperti halnya tari tradisi, dalam suatu etnik merupakan simbolisasi dari kehidupan sosialnya.

Menurut Arbi (1999: 21) tari merupakan proyeksi dari gambaran kehidupan suatu masyarakat. Melalui simbol-simbol gerak tertentu, kostum, maupun penyajian (pertunjukan) secara keseluruhan, tari dapat menyampaikan maksud-maksud atau pun kehendak yang akan diungkap oleh komunitasnya. Tari Balanse Madam, seperti halnya tari tradisi, merupakan ungkapan dari berbagai kehidupan yang ada dalam mas yarakat Nias Kota Padang, seperti ungkapan solidaritas, eksistensi, serta persatuan dan kesatuan.

Tari Balanse Madam: Media Sosialisasi Etnik Nias (Indra Yuda) 
Tari Balanse Madam merupakan tarian yang bersifat hiburan. Bentuk geraknya memiliki karakter keceriaan. Tarian Balanse, seperti kebanyakan tarian Melayu, lebih memfokus pada bentuk gerak joget, step, dan melenggang. Tari Balanse dikatakan juga sebagai tarian sosial karena sering dipertunjukan dalam berbagai acara pesta perkawinan dan upacara penobatan penghulu.

Dengan adanya pertunjukan tari Balanse pada pesta perkawinan, terjalin relasi sosial dari berbagai anggota masyarakat, baik anggota pelaku tarian Balanse, anggota masyarakat yang menonton, maupun pelaksana dari kegiatan pertunjukan Balanse. Dalam pergelaran tari Balanse terjadi interaksi sosial maupun integrasi masyarakat. Karena itu, tarian ini dapat berperan sebagai tarian sosial.

Di samping sebagai tarian hiburan dalam kategori tari sosial, tari Balanse Madam memiliki berbagai keunikan, baik dari segi personalitas, struktur penyajian, etika bergerak, maupun simbol-simbol gerak yang disajikan. Keunikan dari personalitas berupa seluruh penari, baik laki-laki maupun wanita, harus berasal dari orang-orang yang sudah berkeluarga atau yang sedang menjalani proses perkawinan, yang disebut suami atau isteri. Tarian ini tidak dibenarkan ditarikan oleh $d u d a$, janda, ataupun bujang dan gadis. Pada prinsipnya tarian Balanse diatur oleh adat yang berlaku dalam etnik Nias Kota Padang.

Dengan ditarikannya tari Balanse Madam oleh orang-orang yang sudah berkeluarga, pada gilirannya terjadi komunikasi sosial antarpersonalitas yang menari dalam tarian tersebut. Komunikasi dapat berupa tukar pengalaman, saling bercerita tentang kehidupan masing-masing, saling berkenalan, atau mengenal lebih jauh tentang keluarga masing-masing. Relasi sosial ini dapat terus berlanjut di luar arena pertunjukan.

Merujuk pada fenomena di atas, tulisan ini akan mengungkapkan berbagai persoalan tentang tari Balanse sebagai media sosialisasi etnik Nias yang berada di Kota Padang Sumatera Barat. Dampak dari pertunjukan tari Balanse adalah terjadinya interaksi dan relasi antaranggota masyarakat yang ada pada masyarakat Nias di Kota Padang.

\section{B. Metodologi Penelitian}

Penelitian ini dilaksanakan dengan pendekatan kualitatif. Penelitian kualitatif disebut juga penelitian naturalistik. Penelitian kualitatif dengan paradigma naturalistik relevan dengan objek penelitian, yaitu mengetahui dan mengungkapkan makna dan fungsi tari Balanse Madam pada masyarakat Suku Nias di Seberang Palinggam Kota Padang. Unit analisis dalam penelitian ini adalah tari Balanse Madam pada suku Nias di Seberang Palinggam. Peneliti merupakan instrumen utama dan pengumpulan informasi dilakukan dengan teknik snow-ball.

Imaji, Vol.2, No.2, Agustus 2004 : 225 - 234 
Informasi diperoleh melalui observasi terlibat, wawancara mendalam, dan dokumen yang dikumpulkan melalui literatur, hasil penelitian terdahulu, dan rekaman audiovisual. Analisis data bersifat induktif yang dilakukan bersamaan pengumpulan data di lapangan dan setelah seluruh data terkumpul, mengikuti cara yang dilakukan Spradley dengan modifikasi dari 12 langkah menjadi 9 langkah.

\section{Sejarah Tari Balanse Madam dan Etnik Nias Kota Padang}

Sejarah keberadaan tari Balanse Madam tidak terlepas dari kehadiran bangsa Portugis di pantai barat Sumatera pada abad 16. Kedatangan bangsa Portugis di Kota Padang telah membawa dampak terhadap tumbuhnya kesenian di Padang waktu itu, di antaranya tari Balanse Madam dan Musik Gamad. Nosafirman (1998: 2) menjelaskan bahwa satu abad sebelum 7 Agustus 1669, Padang hanya berupa perkampungan tradisional yang terletak di pinggiran pantai Sumatera bagian barat, yang kalah ramai dibanding Tiku dan Pariaman. Namun, kampung itu mulai ramai sejak orang-orang Portugis dan Aceh berdatangan untuk berdagang di Kota Padang.

BK Hura dalam Nosafirman (1998: 22) menjelaskan bahwa dengan kehadiran bangsa Portugis di Padang sebagai pedagang, bersamaan itu pula berdatangan penduduk imigran dari pulau Nias untuk bekerja sebagai buruh atau pembantu untuk bangsa Portugis. Kedatangan orang Nias dibawa oleh para pedagang Cina yang datang ke Sumatera Barat dari pulau Nias pada awal abad 16. Mereka ditempatkan di berbagai daerah, antara lain Padang (terutama di daerah Muara), daerah Pariaman, dan sebagian lain di daerah Muara Sakai Pesisir Selatan. Hanya saja, orang Nias tersebut lebih banyak ditempatkan di Padang.

Dengan dipekerjakannya orang-orang Nias yang berada di Padang, terjadilah relasi sosial budaya antara kedua suku bangsa tersebut, sehingga menularkan suatu bentuk kesenian, yakni tari Balanse Madam. Awal lahirnya tari Balanse Madam adalah akibat seringnya terjadi kontak sosial antara bangsa Portugis sebagai majikan dan orang Nias sebagai bawahan atau pekerja.

Pada setiap pesta yang dilakukan oleh bangsa Portugis, baik di kapal maupun di daratan, selalu diperkenalkan tarian yang berbentuk tari pergaulan, seperti dansa, kepada orang-orang Nias. Bangsa Portugis bukan saja menyebarkan pengaruhnya dalam hal perdagangan, melainkan juga dalam hal kesenian. Etnis yang terdekat dengan komunitas Portugis pada waktu itu adalah orang-orang Nias yang bekerja sebagai pembantu, baik untuk keluarga Portugis maupun dalam kelancaran usaha perdagangannya dan sebagai buruh. Interpretasi orang Nias terhadap peristiwa budaya tersebut, melahirkan berbagai gagasan tentang kesenian yang menjadi modal dasar dalam proses berkesenian yang mereka lakukan 
selanjutnya. Disebabkan seringnya orang Nias menyaksikan pertunjukan kesenian, baik tari maupun musik, yang disajikan oleh bangsa Portugis, lama-kelamaan orang Nias mulai mempelajari dan mengembangkannya melalui suatu proses adaptasi dengan proses transformasi imajiner.

Berdasarkan transformasi imajiner seniman Nias mengembangkan polapola tari dansa dengan mengadopsi berbagai tarian Melayu Minangkabau dan tarian yang berasal dari pulau Nias sendiri, seperti tari Hiwo, Maena, dan Molaya. Pada pertengahan abad 16 tarian Balanse dinyatakan sebagai tarian adat. Hal itu dilakukan mengingat jauhnya jarak dan sulitnya transportasi dari Padang ke pulau Nias, yang lama-kelamaan budaya asli nenek moyang mereka akan hilang. Dengan hilangnya budaya mereka berarti hilang juga identitas mereka. Oleh sebab itu, atas saran pemerintah Belanda dan Sultan Padang, pada pertengahan abad 16 orang Nias mengadakan musyawarah untuk membentuk adat-istiadat baru sekaligus budaya baru yang menjadi identitas orang Nias Kota Padang. Salah satu di antaranya tarian Balanse Madam.

Hingga saat ini tari Balanse masih tetap terpelihara pada masyarakat Nias, bahkan kalangan akademisi mulai mempelajarinya sebagai bahan kajian dalam studi. Begitu juga, adanya perkembangan dunia kepariwisataan dan entertainment menyebabkan tarian Balanse pun berkembang. Bagi etnik Nias tari ini tetap menjadi fokus budaya sekaligus warisan budaya yang tetap mereka pelihara.

Etnik Nias menempati hampir sebagian besar wilayah Kota Padang lama, tepatnya di Kampung Nias, Seberang Palinggam, Simpang Enam, Purus, dan Tabing. Orang Nias dikatakan juga orang Padang, karena orang Niaslah yang pertama kali membuka daerah Kota Padang. Orang Nias pada abad 16 menggarap kebun dan ladang atas suruhan Pemerintah Belanda dan Portugis. Telah diperlebar sebagian Kota Padang oleh orang Nias, hal itu dapat dijumpai dengan beberapa nama dalam bahasa Nias di Kota Padang, seperti Siteba (Sitebai), Hiligoo, dan Banuaran (Banuara). Sejak itu Padang ramai dikunjungi oleh pedagang.

Hingga saat ini orang Nias tetap eksis di daerah yang mereka tempati dari abad 16. Karena perubahan zaman dan evolusi kebudayaan, orang Nias pun telah banyak berasimilasi dengan etnik Minangkabau. Telah banyak pula terjadi kawin campuran antara orang dari suku Nias dan orang Minangkabau. Dalam hal mata pencaharian etnik Nias lebih banyak hidup sebagai buruh, pedagang, dan pengobatan tradisional. Mereka masih ada yang beragama animisme, walaupun sebagian besar telah beragama Islam dan Kristen.

Imaji,Vol.2, No.2, Agustus 2004 : 225 - 234 


\section{Keberadaan Tari Balanse Madam}

Sebagai tarian baru bagi masyarakat Nias yang merantau di Kota Padang, kehadiran tari Balanse Madam dirasa sangat penting. Berdasarkan pandangan yang jauh ke depan dari sebagian besar masyarakat Nias, dari jauhnya jarak antara tanah leluhur dan keberadaan mereka sekarang, lambat laun itu akan bisa melepaskan mereka dari budaya asli nenek moyang mereka. Oleh sebab itu, atas kesepakatan bersama dari para pemuka masyarakat Nias, tari Balanse Madam diangkat secara adat menjadi tari tradisi warisan budaya bagi masyarakat Nias keturunan yang berada di Kota Padang.

Setelah tarian Balanse dikukuhkan secara adat, tarian itu pun disosialisasikan sebagai tarian tradisional orang Nias keturunan (perantau) yang telah menjadi warga Kota Padang. Dengan kedudukannya sebagai tarian adat, maka berdasarkan kesepakatan pemuka masyarakat dengan anggota masyarakat, tarian Balanse Madam diatur secara adat-istiadat oleh orang Nias perantauan atau orangorang Nias Kota Padang agar dapat tumbuh dan berkembang secara berkelanjutan (mentradisi).

Peraturan-peraturan adat yang harus diikuti oleh penari Balanse Madam adalah: (1) masing-masing penari harus orang-orang yang sudah menikah, (2) tidak boleh ada hubungan famili terdekat antara penari pria dan wanita (kakak, adik, ipar, sepupu, dan paman atau bibi), (3) setiap gerakan yang berpeluang bersentuhan langsung dengan telapak tangan, maka telapak tangan itu harus dialasi dengan sehelai saputangan agar terhindar dari kontak langsung, dan (4) sebelum pertunjukan masing-masing penari harus minta izin kepada suami/istri, keluarganya, dan pimpinan adat.

Tari Balanse Madam secara tradisi dan berkesinambungan digunakan oleh masyarakat suku Nias untuk beberapa hal, seperti: (1) upacara adat, (2) hajatan (pesta) perkawinan, (3) hajatan kampung maupun nagari, dan (4) pesta yang berkaitan dengan acara-acara adat lainnya. Kegiatan yang termasuk upacara adat adalah pengangkatan penghulu, kepala kampung, membuka ladang atau kebun. Hajatan kampung misalnya mendirikan balai desa, mengenang orang Nias pertama kali datang ke Padang. Hal yang berkaitan dengan acara adat lainnya adalah soal cilok aek (turun mandi).

Peranan tari Balanse Madam dalam kehidupan sosial masyarakat suku Nias yang hidup, berkembang, dan menetap di daerah Seberang Palinggam adalah: (1) sebagai sarana hiburan, (2) sebagai sarana pelengkap acara dan upacara adat, dan (3) sebagai pertanda status sosial masyarakat. 
Secara tradisi tari Balanse Madam merupakan warisan budaya orang Nias yang ada di Kota Padang. Oleh karena itu, kesenian Balanse lebih hidup dan memang menjadi suatu keharusan untuk dihidupkan dan dikembangkan di masyarakat Nias yang telah menjadi warga Kota Padang. Karena orang-orang Nias sudah diakui menjadi warga Kota Padang, secara tidak langsung tari Balanse Madam menjadi budaya atau kesenian tradisi Kota Padang atas komunitas orangorang Nias Kota Padang. Masyarakat kota secara moral turut mendukung atas keberlangsungan tari Balanse Madam. Dari pengakuan tentang keberadaan tari Balanse Madam di Kota Padang oleh orang Minang yang mayoritas beragama Islam, berarti kesenian Balanse dapat diterima oleh warga Kota Padang sebagai bagian dari kehidupan masyarakat kota. Kesenian Balanse telah diakui sebagai kesenian tradisi yang merupakan warisan budaya dan harus berkelanjutan secara turun-temurun dalam warga masyarakat pemilik tari Balanse itu.

Perkembangan tari Balanse Madam dapat dilihat dari beberapa indikator. Indikator-indikator tersebut adalah: (1) bentuk fisik, (2) tata cara pertunjukan, (3) syarat-syarat pertunjukan, (4) waktu pertunjukan, dan (5) segi kegunaannya.

Pengembangan atas kelima indikator pada tari Balanse Madam masa sekarang tidak mempengaruhi kemurnian dan ketradisian tari Balanse Madam sebelumnya. Pengembangan tersebut diakibatkan oleh adanya perubahan sosial budaya, ekonomi, dan ilmu pengetahuan. Tiga faktor besar itu yang mengakibatkan tarian Balanse Madam dapat berkembang di tengah masyarakat, baik dalam masyarakat Nias, masyarakat luas, maupun masyarakat akademik.

Dari bentuk fisiknya pergeseran tari Balanse Madam dapat dilihat pada: (1) pola lantai, (2) jumlah gerak, (3) bentuk gerak, (4) kostum, (5) syarat-syarat menarikan, (6) tata aturan menampilkan, dan (7) nilai jasa untuk penari maupun pemusik. Dari faktor sosial budayanya kesenian Balanse Madam dipandang bukan saja sebagai kesenian tradisi yang mapan atau hanya sekedar menjadi monumen warisan budaya. Kesenian Balanse tidak lagi dipandang sebagai sesuatu yang sakral dan tidak bisa disentuh oleh tangan kreatif dari segi nilai maupun fungsi dan bentuknya. Karena perubahan sosial budaya, tari Balanse Madam pun berubah menjadi bagian dari kebutuhan ekonomi. 


\section{E. Tari Balanse Madam sebagai Media Sosial}

Pertunjukan tari Balanse Madam adalah sebuah event atau peristiwa, yang di dalam peristiwa itu terbentuk struktur. Dalam struktur yang terbentuk tersebut dapat ditemui antara lain penyaji/pemusik/penari (seniman), penonton, pemuka masyarakat, dan pelaksana kegiatan. Struktur sosial masyarakat Nias di Kota Padang dapat dikenali dari adanya dua orang penghulu yang disebut Penghulu You dan Penghulu Raya. Artinya, dalam masyarakat Nias terdapat penghulu pangkal dan penghulu ujung. Di samping penghulu dikenal juga Ninik Mamak (penghulu marga/ kalangan lelaki dari marga yang sudah dewasa), Kepala Kampung, Tetua Kampung, dan anggota masyarakat.

Pertunjukan tari Balanse diatur menurut adat dengan prosesi menyerahkan sirih dalam cerana kepada penghulu, dilanjutkan menyerahkan sebotol minuman (dahulu berupa minuman keras), minuman tersebut diminum seteguk oleh penghulu dan selanjutnya diserahkan kepada kepala kampung dan anggota pemusik untuk diminum bersama-sama. Segmen selanjutnya, penghulu menunjuk seorang sisindo untuk bertindak memilih penari dan anggota masyarakat yang ada dalam pesta tersebut (biasanya pesta perkawinan). Penari yang terpilih kemudian dipasangkan satu dengan yang lain, sebanyak empat pasang, oleh sisindo yang berasal dari pasangan suami-istri yang berbeda.

Selanjutnya, salah seorang Komander (pengendali jalannya pertun-jukan tari) memanggil penari ke panggung. Atas perintah Komander tarian dimulai, begitu juga aba-aba dari Komander menentukan panjang pendek atau bentuk ragam gerak yang akan dilakukan oleh penari, hingga tarian berakhir. Pada sesi atau segmen berikutnya, penari diganti dengan pasangan yang baru lagi, begitu seterusnya hingga dini hari. Tari Balanse biasanya dimulai pukul sepuluh malam hingga Subuh. Secara adat berakhirnya tarian ditentukan oleh penghulu.

Sebagai media sosial, tarian Balanse berperan dalam membentuk integrasi masyarakat. Dengan adanya peristiwa pertunjukan tari Balanse Madam segala kategori sosial maupun struktur masyarakat akan terhimpun menjadi satu kesatuan. Peristiwa tersebut menjadi ajang komunikasi atau sosialisasi antara satu keluarga dan keluarga yang lain, baik dalam satu marga (suku) maupun dengan suku lainnya dalam etnik Nias. Ajang tersebut juga dijadikan tempat menumbuhkan rasa saling menghargai, saling menghormati keberadaan masing-masing anggota masyarakat.

Dalam pertunjukan tari Balanse terjadi berbagai dialog, menyangkut masalah keluarga, pekerjaan, situasi sosial, dan berbagai pengalaman hidup yang dihadapi. Bagi generasi muda, kegiatan tersebut dijadikan tempat menimba penge tahuan tentang identitas kultural mereka. Dengan melihat pertunjukan tari Balanse Madam generasi muda etnik Nias dapat belajar mengetahui kehidupan

Tari Balanse Madam: Media Sosialisasi Etnik Nias (Indra Yuda) 
berrumah tangga, saling menghargai status perkawinan, dan menghormati eksistensi orang lain sebagai bagian dari anggota masyarakat.

Pertunjukan (pertunjukan) tari Balanse Madam, menimbulkan suatu integrasi sosial antara berbagai struktur yang ada dalam masyarakat Nias. Dengan adanya peristiwa Balanse, maka tidak ada lagi berbicara masalah stratafikasi, yang ada hanya penari dan pemusik serta penonton. Secara filosofi keseluruhan unsur berpadu dan menyatu dalam konteks pertunjukan kesenian.

Pertunjukan tersebut menjadi media (alat) bagi masyarakat Nias untuk berkumpul, menyatu, berbagi pengalaman, maupun saling mengakui keberadaan masing-masing sebagai bagian dari anggota masyarakatnya. Pertunjukan tari Balanse Madam telah menjadi jembatan bagi masyarakat untuk saling mengenal satu dengan yang lain. Dengan adanya peristiwa tersebut, terjadilah relasi, interaksi yang positif dan menyebabkan ter-bentuknya integrasi sosial, pada gilirannya dapat mempererat silaturahmi antarwarga masyarakat etnik Nias.

Pertunjukan tari Balanse juga merupakan tempat pengeksistensian diri bagi orang-orang yang telah berumah tangga. Dengan ditunjuknya mereka untuk menari, secara tidak langsung seluruh masyarakat yang hadir pada peristiwa tersebut dapat mengetahui statusnya. Begitu juga terhadap penghulu dan ninik mamak, masyarakat akan mengetahui siapa penghulu itu sebenarnya dan siapa pula ninik mamak dari marga (suku) yang lain. Dengan demikian, tari Balanse dikatakan juga sebagai media sosial bagi etnik Nias yang ada di Kota Padang.

\section{F. Penutup}

Tarian Balanse merupakan tarian warisan budaya etnik Nias yang telah menjadi warga Kota Padang sejak abad 16. Sebagai tari tradisional, tari Balanse diatur secara adat-istiadat oleh masyarakat Nias yang ada di Padang.

Keberadaan tari Balanse Madam pada dewasa ini, di samping sebagai tarian adat (tradisi) dan sebagai fokus kebudayaan, juga menjadi bahan studi atau kajian secara akademik bagi perguruan tinggi seni maupun sekolah seni yang ada di Kota Padang. Di samping itu, tarian itu juga menjadi sumber garapan bagi grupgrup seni pertunjukan yang ada di Padang dalam rangka mendukung pertumbuhan kepariwisataan. Meskipun demikian, keaslian tarian itu tetap terjaga.

Tarian Balanse juga merupakan jembatan komunikasi antarwarga dalam masyarakat etnik Nias. Sebagai tarian yang berfungsi sosial, tari Balanse dapat membangun relasi sosial antarwarga masyarakat. Di samping itu, tarian Balanse juga berperan sebagai media interaksi yang kemudian berdampak positif dalam

Imaji, Vol.2, No.2, Agustus 2004 : 225 - 234 
membentuk integrasi sosial. Pada gilirannya, integrasi akan semakin merapatkan struktur sosial dan menafikan terjadinya konflik sosial. Adanya pergelaran Balanse semakin memperkokoh solidaritas dari warga etnik Nias di Kota Padang.

\section{DAFTAR PUSTAKA}

Arbi, Alfar. 1999. Masyarakat Nias dan Perdagangan Tempo Dulu di Kota Padang. Padang: PPS UNP.

Erwanto. 1998. Analisis Bentuk Penyajian Tari Balanse Madam. Padang: FPBS IKIP Padang.

Garna, Judistira K. 1996. Ilmu-ilmu Sosial, Dasar-Konsep-Posisi. Bandung: PPS UNPAD.

Geertz, Clifford (terj. F.B. Hardiman). 1992. Tafsir Kebudayaan. Yogyakarta: Kanisius.

Gulo, Anatona. 1995. Adaptasi Masyarakat Nias di Kota Padang: Suatu Tinjauan dari Segi Bahasa. Padang: LEMLIT Universitas Andalas.

Harefa, Orbavianus. 1995. Kehidupan Pemuda Nias di Kota Padang dan Implikasinya. Padang: IKMNP.

Koetjaraningrat. 1987. Sejarah Teori Antropologi I. Jakarta: UI Press. . 1990. Sejarah Teori Antropologi II. Jakarta: UI Press.

Langer, Suzanne K. 1998. Problem of Art. New York: New York Publisher Inc.

Martin, John. 1963. The Modern Dance. New York: Horizon.

Royce, Anya Peterson. 1981. Dance Antropology. Indiana: Indiana Univercity Press.

Siregar, Miko. 1996. Tindak Ritual dan Konteks Kepariwisataan dalam - Pertunjukan Tabut di Pariaman. Padang: FPBS IKIP Padang.

Soenarto. 1989. Wawasan Seni. Yogyakarta: FPBS IKIP Yogyakarta.

Syarif, Mustika. 1981. Tari Tradisional Minangkabau. Padang: Bidang Kesenian Kanwil Dikbud Sumbar. 